\title{
Deficiency of 3-Methylglutaconyl-Coenzyme A Hydratase in Two Siblings with 3-Methylglutaconic Aciduria
}

\author{
Kuniaki Narisawa, Kenneth M. Gibson, Lawrence Sweetman, and William L. Nyhan \\ Department of Pediatrics, M-009, University of California, San Diego, La Jolla, California 92093 \\ Marinus Duran and Sybe K. Wadman \\ University Children's Hospital "Het Wilhelmina Kinderziekenhuis," 3512 LK Utrecht, The Netherlands
}

\begin{abstract}
We studied two patients with 3-methylglutaconic aciduria in order to determine the molecular defect. A new assay for 3-methylglutaconyl-coenzyme A (CoA) hydratase has been developed in which the substrate, $\left[5-{ }^{14} \mathrm{C}\right] 3-$ methylglutaconyl-CoA, was synthesized using 3-methylcrotonyl-CoA carboxylase purified from bovine kidney. In this assay the products of the reaction are isolated by reverse-phase high performance liquid chromatography and the rates of conversion from substrate are measured. The Michaelis constant for 3-methylglutaconyl-CoA in normal fibroblasts was $6.9 \mu \mathrm{mol} / \mathrm{liter}$. The mean activity of 3-methylglutaconyl-CoA hydratase in control fibroblasts was 495 pmol/ min per mg protein. In the two patients the values were 11 and $17 \mathrm{pmol} / \mathrm{min}$ per $\mathrm{mg}$ protein, or $2-3 \%$ of normal.
\end{abstract}

\section{Introduction}

3-Methylglutaconic aciduria is a recently described disorder of leucine metabolism, characterized by an abnormal organic acid profile in which there is excessive excretion of 3-methylglutaconic acid and 3-methylglutaric acid (1-4). Nine patients have been reported to have this disorder (1-6). Most of these patients (2, 3,5 ) appeared normal for the first 4-9 mo of life, then developed severe neurological degeneration. In two siblings (1) the phenotype was very different. Prominent clinical manifestations were limited to retardation of speech, and large quantities of 3-hydroxyisovaleric acid, as well as 3-methylglutaconic acid and 3methylglutaric acid, were excreted in the urine. These compounds are all on the degradative pathway for leucine (Fig. 1). In these patients the excretion of 3-hydroxy-3-methylglutaric acid $(\mathrm{HMG})^{1}$ was not elevated. Therefore, it has been postulated that the site of the enzyme defect is in the enzyme, 3-methyl-

Dr. Narisawa is on leave from the Department of Pediatrics, Tohoku University School of Medicine, Sendai 980, Japan. Address reprint requests to Dr. Sweetman.

Received for publication 6 November 1984

1. Abbreviations used in this paper: $\mathrm{CoA}$, coenzyme A; 3-HB, 3-hydroxybutyric acid; HMG, 3-hydroxy-3-methylglutaric acid; HMG-CoA, 3-hydroxy-3-methylglutaryl-CoA; HPLC, high performance liquid chromatography; i.d., inside diameter; MCC, 3-methylcrotonyl-CoA-carboxylase; 3-MG-CoA, 3-methylglutaconyl-CoA.

J. Clin. Invest.

(C) The American Society for Clinical Investigation, Inc.

$0021-9738 / 86 / 04 / 1148 / 05 \quad \$ 1.00$

Volume 77, April 1986, 1148-1152 glutaconyl-coenzyme A (CoA) hydratase (E.C. 4.2.1.18) (7). However, this has not previously been established. We have developed a new method for the direct assay of 3-methylglutaconylCoA hydratase (3-MG-CoA hydratase). We have studied fibroblasts derived from the two siblings described by Duran et al. (1), and have documented a deficiency of 3-MG-CoA hydratase.

\section{Methods}

Materials. Adenosine-5'-triphosphate (ATP), NADH, 3-methylcrotonylCoA, 3-hydroxybutyrate dehydrogenase (Type IV), polyethylene glycol 6000, and DEAE cellulose were purchased from Sigma Chemical Co. (St. Louis, MO). Sephadex G-10, Sepharose 6B, and DEAE-Sephadex A-25 resins were obtained from Pharmacia Fine Chemicals (Piscataway, NJ). Hydroxylapatite (Bio-Gel HTP) was purchased from Bio-Rad Laboratories (Richmond, $\mathrm{CA}$ ) and PM 10 ultrafiltration membranes were obtained from Amicon Corp. (Danvers, MA). $\mathrm{NaH}^{14} \mathrm{CO}_{3}(9.2 \mathrm{mCi} / \mathrm{mmol}$ ) was purchased from New England Nuclear (Boston, MA). All other reagents were of the highest purity available. The reverse-phase high performance liquid chromatography (HPLC) column employed has been described by DeBuysere and Olson (8).

Purification of 3-methylcrotonyl-CoA carboxylase (MCC). For the enzymatic synthesis of $\left[5-{ }^{14} \mathrm{C}\right] 3-\mathrm{MG}-\mathrm{CoA}, \mathrm{MCC}$ was purified from frozen bovine kidney by a modification of the method of Lau et al. (9). The MCC in the crude extract was precipitated with polyethylene glycol 6000 and chromatographed on DEAE cellulose. Blue dextran-Sepharose chromatography was omitted. Instead, after hydroxylapatite chromatography, gel filtration was performed on a column of Sepharose 6B (1 $\mathrm{cm}$ inside diameter [i.d.] $\times 47.5 \mathrm{~cm}$ ) equilibrated and eluted with 20 $\mathrm{mmol} /$ liter potassium phosphate buffer, $\mathrm{pH} 7.0$, containing $0.1 \mathrm{mmol} /$ liter EDTA, $0.1 \mathrm{mmol} /$ liter dithiothreitol, and $10 \%$ glycerol. The specific activity of the 600 -fold purified MCC was $1.6 \mu \mathrm{mol} / \mathrm{min}$ per mg protein and the yield was $6 \%$. MCC activity was assayed in 100- $\mu$ lassays modified from the method described by Weyler et al. (10), by fixation of $\mathrm{NaH}^{14} \mathrm{CO}_{3}$ into acid nonvolatile products using 3-methylcrotonyl-CoA and ATP as substrates.

Preparation of $\left[5-{ }^{14} \mathrm{C}\right] 3-\mathrm{MG}-\mathrm{CoA}$. The product of MCC is the trans isomer ( $E$-form) of 3-MG-CoA (11). That this is the isomer which is the substrate for 3-MG-CoA hydratase is indicated by the fact that $E$-3-MG$\mathrm{CoA}$ is the product of the reverse reaction, the dehydration of 3-hydroxy3-methylglutaryl-CoA (HMG-CoA) catalyzed by 3-MG-CoA hydratase (12). The purified MCC was used for the enzymatic synthesis of [5$\left.{ }^{14} \mathrm{C}\right] E$-3-MG-CoA from $\mathrm{NaH}^{14} \mathrm{CO}_{3}$, 3-methylcrotonyl-CoA, and ATP. Purified MCC ( $\sim 0.025 \mathrm{U})$ was added to $1 \mathrm{ml}$ of solution consisting of $100 \mathrm{mmol} /$ liter Tris- $\mathrm{HCl}, \mathrm{pH} 8.0,50 \mathrm{mmol} /$ liter $\mathrm{KCl}, 8 \mathrm{mmol} / \mathrm{liter}$ $\mathrm{MgCl}_{2}, 0.25 \mathrm{mmol} / \mathrm{liter}$ EDTA, $3 \mathrm{mmol} / \mathrm{liter}$ ATP, $1.8 \mathrm{mmol} / \mathrm{liter} 3-$ methylcrotonyl-CoA, and $10 \mathrm{mmol} /$ liter $\mathrm{NaH}^{14} \mathrm{CO}_{3}(9.2 \mathrm{mCi} / \mathrm{mmol})$. The mixture was incubated for $2 \mathrm{~h}$ at $30^{\circ} \mathrm{C}$. The $\mathrm{pH}$ was adjusted to 23 with $5 \mathrm{~mol} /$ liter $\mathrm{HCl}$, and unreacted $\mathrm{H}^{14} \mathrm{CO}_{3}^{-}$was removed as ${ }^{14} \mathrm{CO}_{2}$ by the addition of small pieces of dry ice. The $\left[5-{ }^{14} \mathrm{C}\right] 3-\mathrm{MG}-\mathrm{CoA}$ product was purified by chromatography on a DEAE-Sephadex A-25 column $(0.6 \mathrm{~cm}$ i.d. $\times 30 \mathrm{~cm})$ using a linear gradient of $\mathrm{LiCl}(140 \mathrm{ml} 0.065 \mathrm{~mol} /$ liter to $140 \mathrm{ml} 0.2 \mathrm{~mol} / \mathrm{liter}$ ) in $5 \mathrm{mmol} / \mathrm{liter} \mathrm{HCl}$, modified from the 


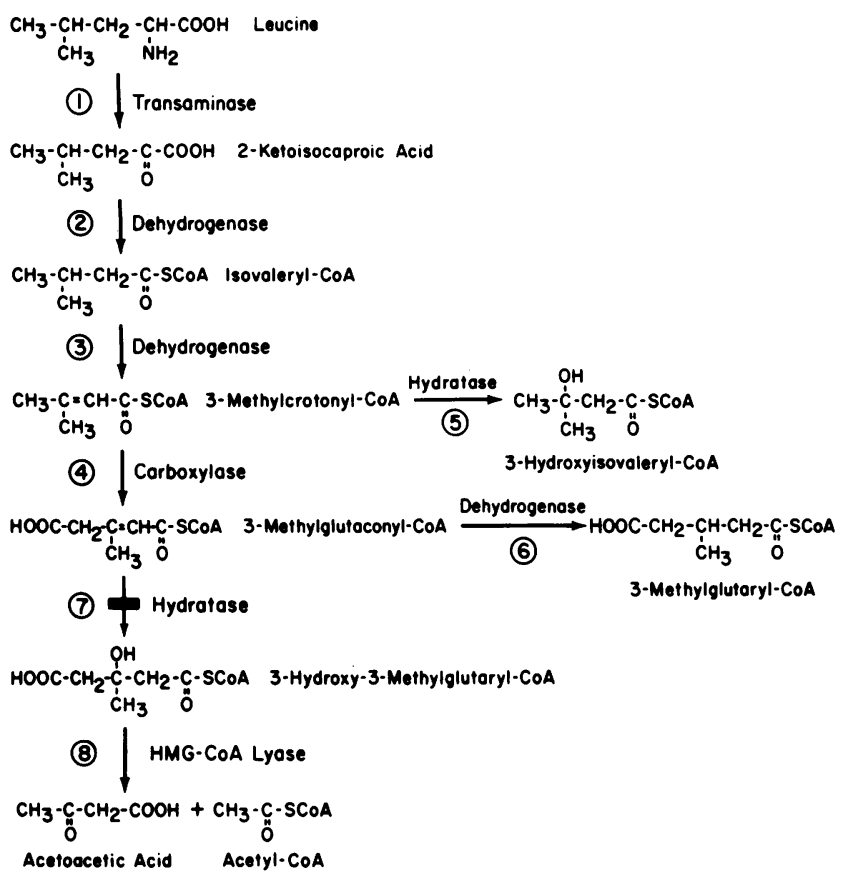

Figure 1. Catabolic pathway for leucine. The 3-MG-CoA hydratase is numbered 7.

method of Bartlett et al. (13). Chromatography was performed at room temperature and a flow rate of $0.7 \mathrm{ml} / \mathrm{min}$. The fractions containing [5$\left.{ }^{14} \mathrm{C}\right] 3-\mathrm{MG}-\mathrm{CoA}$ were pooled, lyophilized, and $\mathrm{LiCl}$ was removed by chromatography on a Sephadex G-10 column $(0.6 \mathrm{~cm}$ i.d. $\times 50 \mathrm{~cm})$, equilibrated and eluted with distilled water.

The specific activity of the purified $\left[5-{ }^{14} \mathrm{C}\right] 3-\mathrm{MG}-\mathrm{CoA}$ was determined by enzymatic hydration to $\left[5-{ }^{14} \mathrm{C}\right] \mathrm{HMG}-\mathrm{CoA}$ with excess crotonase (Sigma Chemical Co.) and comparison of this with authentic [3$\left.{ }^{14} \mathrm{C}\right] \mathrm{HMG}-\mathrm{CoA}$ of known specific activity $(5.5 \mathrm{mCi} / \mathrm{mmol}$ ) (New England Nuclear). Both compounds were analyzed by reverse-phase HPLC (8) with the quantities determined from chromatographic peak areas with a 254-nm detector, and the radioactivity in collected fractions was determined with a liquid scintillation counter. The results were corrected for recoveries of authentic $\left[3-{ }^{14} \mathrm{C}\right] \mathrm{HMG}-\mathrm{CoA}$. The mean value for duplicate determinations of the specific activity of $\left[5-{ }^{14} \mathrm{C}\right] \mathrm{HMG}-\mathrm{CoA}$ derived from $\left[5-{ }^{14} \mathrm{C}\right] 3-\mathrm{MG}-\mathrm{CoA}$ was $5.8 \mathrm{mCi} / \mathrm{mmol}$. This was $63 \%$ of the specific activity of the precursor $\mathrm{NaH}^{14} \mathrm{CO}_{3}$, indicating considerable dilution by atmospheric $\mathrm{CO}_{2}$ in the $\mathrm{pH} 8$ buffer during the enzymatic synthesis of [5- $\left.{ }^{14} \mathrm{C}\right] 3-\mathrm{MG}-\mathrm{CoA}$. The mean radiochemical purity on reverse-phase HPLC of the $\left[5-{ }^{14} \mathrm{C}\right] \mathrm{HMG}-\mathrm{CoA}$ derived from $\left[5-{ }^{14} \mathrm{C}\right] 3-\mathrm{MG}-\mathrm{CoA}$ was $69 \%$, with essentially all of the rest of the radioactivity in $\left[{ }^{14} \mathrm{C}\right] 3$-methylglutaconic acid, which presumably came from nonspecific hydrolysis of $\left[5-{ }^{14} \mathrm{C}\right] 3-\mathrm{MG}-\mathrm{CoA}$. In the assays of 3-MG-CoA hydratase, after incubation the CoA esters were hydrolyzed and on chromatography the $\left[{ }^{14} \mathrm{C}\right] 3$-methylglutaconic acid represents both $\left[5-{ }^{14} \mathrm{C}\right] 3-\mathrm{MG}-\mathrm{CoA}$ substrate and $\left[{ }^{14} \mathrm{C}\right] 3$-methylglutaconic acid impurity (Fig. 2, bottom). The concentration of substrate $\left[5-{ }^{14} \mathrm{C}\right] 3-\mathrm{MG}-\mathrm{CoA}$ was determined by measuring its radioactivity and correcting for a specific activity of $5.8 \mathrm{mCi} / \mathrm{mmol}$ and radiochemical purity of $69 \%$. The amounts of radioactive products of 3-MG-CoA hydratase were calculated from the specific activity of 5.8 $\mathrm{mCi} / \mathrm{mmol}$. The solution containing $\left[5-{ }^{14} \mathrm{C}\right] 3-\mathrm{MG}-\mathrm{CoA}$ was concentrated to $0.27 \mathrm{mmol} /$ liter and stored at $-20^{\circ} \mathrm{C}$.

3-MG-CoA hydratase assay. Fibroblasts derived from two siblings with 3-methylglutaconic aciduria (1) and control subjects were cultured in Eagle's minimal essential medium with $10 \%$ fetal calf serum. The cells were harvested by trypsinization, pelleted by centrifugation, and washed with Tris-buffered saline. Lymphocytes were isolated from whole venous blood by density gradient centrifugation (14). Fibroblast or lymphocyte

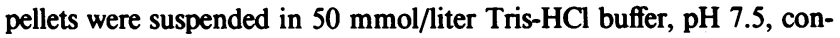
taining $0.75 \mathrm{mmol} /$ liter $\mathrm{Na}_{2}$ EDTA $\left(\sim 5 \times 10^{6}\right.$ cells $\left./ \mathrm{ml}\right)$. The cell suspensions were lysed while chilled in an ice bath by sonic disruption for $2 \times 10 \mathrm{~s}(28 \mathrm{~W})$ with a 60 -s pause between bursts using a Sonifer Cell Disruptor Model W-185 (Heat Systems Ultrasonics, Inc., Farmingdale, NY).

The standard assay contained (final volume, $100 \mu \mathrm{l}$ ): cell sonicate ( $\sim 20-30 \mu \mathrm{g}$ protein), $100 \mathrm{mmol} /$ liter potassium-phosphate buffer, $\mathrm{pH}$ $7.0,0.055 \mathrm{mmol} /$ liter $\left[5-{ }^{14} \mathrm{C}\right] 3-\mathrm{MG}-\mathrm{CoA}(\sim 0.032 \mu \mathrm{Ci}), 3$-hydroxybutyrate dehydrogenase $(2.5 \mathrm{U} / \mathrm{ml})$, and $2 \mathrm{mmol} /$ liter NADH. The mixture without cell sonicate constituted the blank control. Incubations were carried out at $30^{\circ} \mathrm{C}$ for $30 \mathrm{~min}$. The reaction was stopped by the addition of $10 \mu \mathrm{l}$ of ice cold $4.2 \mathrm{~mol} / \mathrm{liter}$ perchloric acid. The solution was centrifuged for $1 \mathrm{~min}$ at top speed in an Eppendorf microcentrifuge. The resultant supernatant fluid was neutralized by addition of $13 \mu \mathrm{l}$ of 1.5 $\mathrm{mol} /$ liter potassium carbonate solution containing $0.25 \mathrm{~mol} / \mathrm{liter}$ triethanolamine. Insoluble potassium perchlorate was removed by centrifugation. The resulting supernatant was adjusted to $\mathrm{pH} 11-12$ by addition of $\sim 23 \mu \mathrm{l}$ of $1 \mathrm{~mol} / \mathrm{liter} \mathrm{KOH}$. The sample was cooled on ice and centrifuged for $1 \mathrm{~min}$ at top speed. The resulting supernatant fluid was transferred to another tube and coenzyme-A esters were hydrolyzed by heating at $60^{\circ} \mathrm{C}$ for $30 \mathrm{~min}$. The hydrolyzed sample was adjusted to $\mathrm{pH}$ $2-3$ by addition of $1 \mathrm{~mol} / \mathrm{liter}$ phosphoric acid $(\sim 38 \mu \mathrm{l})$ and $100 \mu \mathrm{l}$ were analyzed by HPLC.

Reverse-phase chromatography of radioactive products. A guard column $(0.41 \mathrm{~cm}$ i.d. $\times 2 \mathrm{~cm})$ filled with SC30-40 micron reverse-phase C18 ODS pellicular particles was connected to a $0.46 \mathrm{~cm}$ i.d. $\times 25 \mathrm{~cm}$ Spherisorb ODS II, 5-micron column (Custom LC, Inc., Houston, TX). The mobile-phase solvents were $0.05 \mathrm{~mol} / \mathrm{liter}$ potassium-phosphate buffer, pH 2.1 (Buffer A), from 0 to 35 min of elution, 55\% Buffer A and $45 \%$ methanol from 35 to $60 \mathrm{~min}$ of elution, followed by $30 \mathrm{~min}$ of Buffer $\mathrm{A}$ to return to the starting conditions. The chromatographic
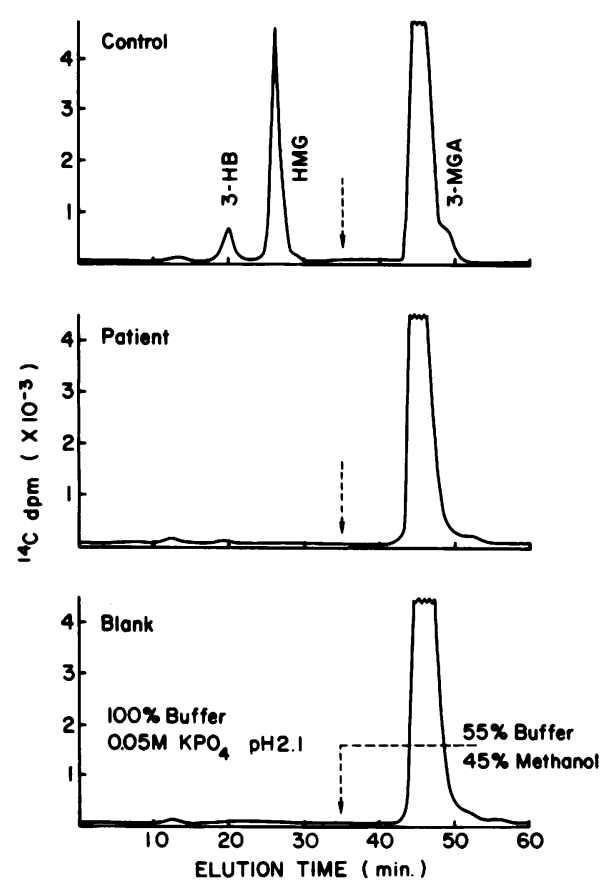

Figure 2. Reverse-phase HPLC separation of the hydrolyzed reaction mixtures after the assay of 3-MG-CoA hydratase in fibroblast lysates. 3-MGA, 3-methylglutaconic acid. The arrow designates the time at which the eluting buffer was changed. 

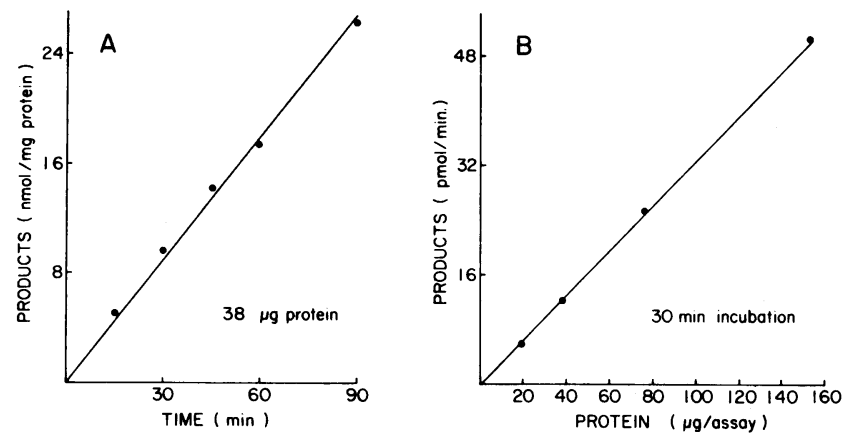

Figure 3. Linearity of the assay for the activity of 3-MG-CoA in normal fibroblast lysates with time $(A)$ and with protein content $(B)$. The points plotted represent the sums of the products, $\left[{ }^{14} \mathrm{C}\right] 3$-hydroxybutyric acid and $\left[{ }^{14} \mathrm{C}\right] 3$-hydroxy-3-methylglutaric acid.

separations were performed at room temperature and a flow rate of 0.44 $\mathrm{ml} / \mathrm{min}$, and 1-min fractions were collected. Radioactivity was determined by liquid scintillation counting with $5 \mathrm{ml}$ of fluor. Studies on the separation of the substrates and products as acyl-CoA esters by reverse-phase HPLC (8) showed that there was a small amount of isomerization of the substrate $E$-3-MG-CoA to Z-3-MG-CoA. The Z-isomer coeluted with HMG-CoA, the product of 3-MG-CoA hydratase. Therefore, the acylCoA substrates and products were hydrolyzed with base to the acids, and the reverse-phase HPLC conditions were modified to separate the free acids. The base hydrolysis caused considerable isomerization of the free 3-methylglutaconic acid.

\section{Results}

The assay of 3-MG-CoA hydratase utilized as substrate $\left[5-{ }^{14} \mathrm{C}\right] 3-$ MG-CoA prepared enzymatically and the products were analyzed by reverse-phase HPLC after hydrolysis of the CoA esters to free acids. 3-Hydroxybutyrate dehydrogenase and NADH were included in the assays because the product $\left[{ }^{14} \mathrm{C}\right] 3$-hydroxy-3methylglutaryl-CoA (HMG-CoA) is partially cleaved by endogenous HMG-CoA lyase to yield $\left[{ }^{14} \mathrm{C}\right]$ acetoacetate. The $\left[{ }^{14} \mathrm{C}\right]$ acetoacetate was therefore converted to the more stable $\left[{ }^{14} \mathrm{C}\right] 3$-hydroxybutyric acid in the reaction catalyzed by 3 -hydroxybutyrate dehydrogenase.
Fig. 2 shows reverse-phase HPLC chromatograms of reaction mixtures for the assay of 3-MG-CoA hydratase. In control fibroblast lysates there were significant radioactive peaks of $\left[{ }^{14} \mathrm{C}\right] 3$ hydroxybutyric acid (3-HB) and $\left[{ }^{14} \mathrm{C}\right] 3$-hydroxy-3-methylglutaric acid (HMG), whereas in these areas essentially no activity was detectable in the assay blank, which lacked cell lysate. In the assay of fibroblasts from patient 1 with 3-methylglutaconic aciduria, no peaks of radioactivity were found in the areas of 3hydroxybutyric acid and HMG.

The activity of 3-MG-CoA hydratase was calculated as the sum of the isotope in the products 3-hydroxybutyric acid and HMG and expressed as $\mathrm{pmol} / \mathrm{min}$ per $\mathrm{mg}$ protein. The activity of the enzyme in fibroblast sonicates was proportional to the time of incubation up to at least $90 \mathrm{~min}$ (Fig. $3 \mathrm{~A}$ ) and to protein concentration up to at least $150 \mu \mathrm{g}$ protein per assay (Fig. $3 \mathrm{~B}$ ). In lymphocyte sonicates enzyme activity was proportional to the time of incubation up to at least $60 \mathrm{~min}$ and to protein concentration up to at least $90 \mu \mathrm{g}$ protein per assay.

The kinetic properties of the enzyme in fibroblast and lymphocyte lysates were determined. 3-MG-CoA hydratase activity in fibroblasts from three different controls followed very similar curves (Fig. $4 A$ ) as a function of 3-MG-CoA concentration. Fig. $4 B$ shows Lineweaver-Burk plots of the same data. The mean Michaelis constant $\left(K_{\mathrm{m}}\right)$ value for 3-methylglutaconyl-CoA in control fibroblasts was $6.9 \mu \mathrm{mol} /$ liter (range, 6.5 to 7.5 ) and the values of maximum velocity $\left(V_{\max }\right)$ ranged from 568 to 614 $\mathrm{pmol} / \mathrm{min}$ per $\mathrm{mg}$ protein. The $K_{\mathrm{m}}$ values for normal lymphocytes were 9.3 and $9.5 \mu \mathrm{mol} /$ liter and the $V_{\max }$ values for normal lymphocytes were 1,089 and $1,359 \mathrm{pmol} / \mathrm{min}$ per $\mathrm{mg}$ protein. The total activity of 3-MG-CoA hydratase in control fibroblast sonicate did not vary greatly with changing $\mathrm{pH}$ from $\mathrm{pH} 6.0$ to 8.0 (Fig. 5), although there was an optimum at $\mathrm{pH} 7.0$ to 7.5. The proportion of isotopes in HMG was much greater at $\mathrm{pH}$ below 7.0, whereas above 7.0 the proportion of total isotope found in 3-hydroxybutyric acid increased appreciably.

On the basis of the data obtained the standard assay was developed and incubations were carried out for $30 \mathrm{~min}$ at $30^{\circ} \mathrm{C}$ in the presence of $0.055 \mathrm{mmol} / \mathrm{liter}$ of $\left[5-{ }^{14} \mathrm{C}\right] 3-\mathrm{MG}-\mathrm{CoA}$. The mean activity in lymphocytes from four normal individuals, each assayed one time, was $822 \mathrm{pmol} / \mathrm{min}$ per $\mathrm{mg}$ protein with a range of 442 to 1,103 . The data on the activities of 3-MG-CoA

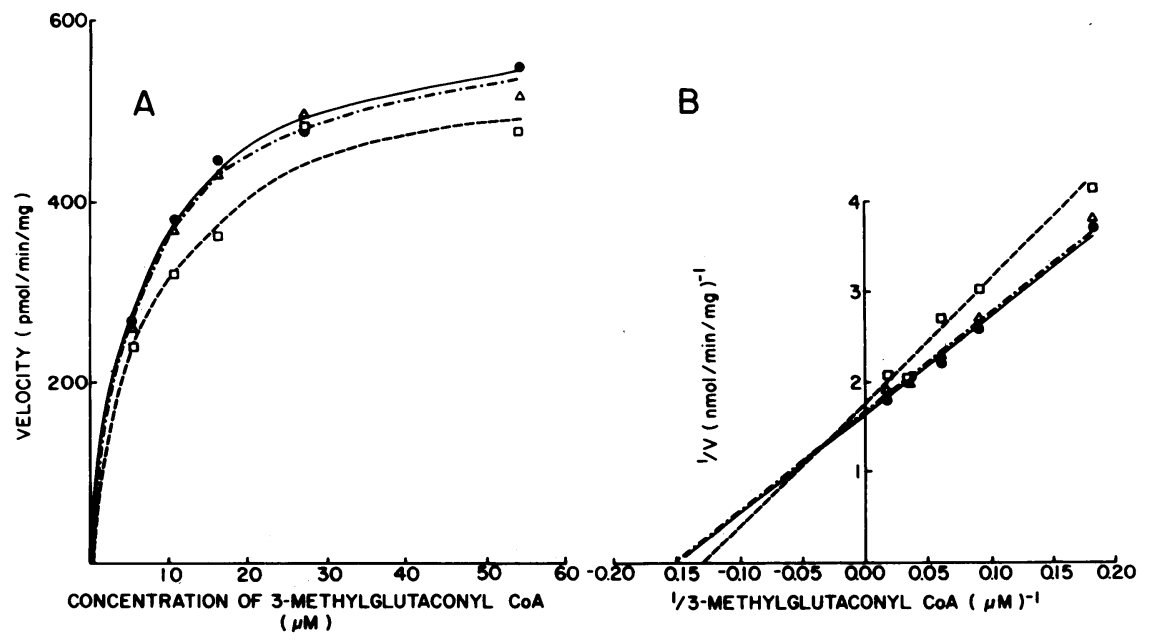

Figure 4. Kinetics of the activity of 3-MG-CoA hydratase in lysates of fibroblasts derived from three different control individuals. $(A)$ Michaelis-Menten plot. (B) Lineweaver-Burk plot. 


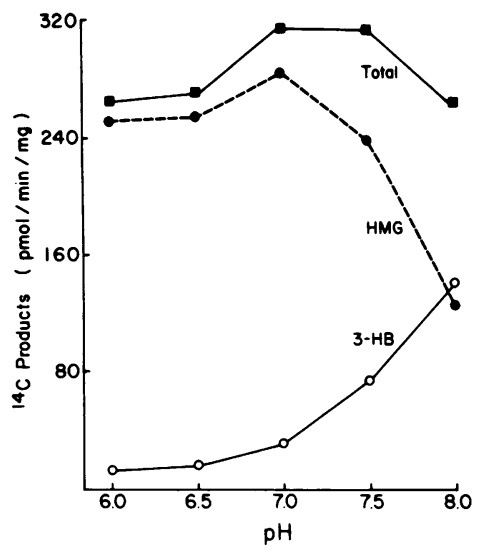

Figure 5. pH activity profile. ${ }^{14} \mathrm{C}$-products of [5$\left.{ }^{14} \mathrm{C}\right] 3$-methylglutaconylCoA in a control fibroblast sonicate as a function of $\mathrm{pH}$.

hydratase in lysates prepared from fibroblasts of the two patients with 3-methylglutaconic aciduria and five controls are shown in Table I. The mean value for controls was $495 \mathrm{pmol} / \mathrm{min}$ per mg protein. Enzyme activities for patients 1 and 2 were 11 and $17 \mathrm{pmol} / \mathrm{min}$ per $\mathrm{mg}$ protein, or $\sim 2-3 \%$ of normal.

\section{Discussion}

We have developed a new method for the assay of 3-MG-CoA hydratase. In this assay the substrate was $\left[5-{ }^{14} \mathrm{C}\right] 3-\mathrm{MG}-\mathrm{CoA}$ synthesized in the reaction catalyzed by 3-methylcrotonyl-CoA carboxylase purified from bovine kidney. The products of the hydratase reaction were isolated, their isotope content determined, and the sum of the products formed from the precursor were the measure of the activity of the enzyme. The reaction was linear with time and enzyme content. $K_{\mathrm{m}}$ values for 3-methylglutaconyl-CoA in normal human fibroblasts and lymphocytes were $\sim 6.9$ and $9.4 \mu \mathrm{mol} /$ liter, respectively.

Using this method, the activity of 3-MG-CoA hydratase was determined in fibroblasts from two patients with 3-methylglutaconic aciduria. A marked deficiency of enzyme activity was found in the two siblings, which provided direct evidence for a deficiency of the hydratase in these patients. Defects in all eight

Table I. 3-Methylglutaconyl-CoA Hydratase Activity in Cultured Fibroblasts of Patients with 3-Methylglutaconic Aciduria and Controls

\begin{tabular}{ll}
\hline Subject & Hydratase activity \\
\hline Control & pmol/min per mg protein \\
$1(n=3)$ & $593 \pm 30$ \\
$2(n=3)$ & $498 \pm 67$ \\
$3(n=3)$ & $485 \pm 29$ \\
$4(n=3)$ & $542 \pm 29$ \\
$5(n=4)$ & $\underline{355 \pm 24}$ \\
\hline Mean of controls ( \pm 1 SD) & $495 \pm 89$ \\
Patient & \\
$1(n=3)$ & $11 \pm 4$ \\
$2(n=3)$ & $17 \pm 5$
\end{tabular}

$n=$ number of determinations. enzymes involved in leucine degradation have now been reported.

The patients studied had a phenotype different from other patients in whom 3-methylglutaconic aciduria has been described (2-6). The similarities of the siblings we have studied indicate that this is the clinical picture of 3-MG-CoA hydratase deficiency. Both had retardation of speech development (1). In one this was the only abnormality. His older brother was also slow in motor development, having walked first at $2 \mathrm{yr}$ of age, and had a short attention span. He had had an unexplained episode of unconsciousness which lasted nearly a day. He responded to an 18-h fast with symptomatic hypoglycemia and a metabolic acidosis. Fasting did not produce hypoglycemia in his sibling. 3-MGCoA hydratase deficiency is likely to be an autosomal recessively transmitted disorder. There was no known consanguinity of the parents of our patients. The assay developed should be suitable for the detection of heterozygosity, but fibroblasts on the parents have not been available for study. Two siblings reported from Sweden had a slowly progressive encephalopathy, but the amounts of 3-methylglutaconic acid excreted in the urine were considerably smaller than in the patients we studied with 3-MGCoA hydratase deficiency. Two other infants reported from Sweden (3) had a similar progressive neurologic degenerative disease. We have studied the activity of 3-MG-CoA hydratase in fibroblasts from three patients with a similar clinical picture $(4,5)$ and found it to be normal $(6)$. Thus, the neurological degenerative form of 3-methylglutaconic aciduria does not appear to be due to a primary deficiency of 3-MG-CoA hydratase.

\section{Acknowledgments}

This work was supported in part by U. S. Public Health Service grant HD 04608 from the National Institute of Child Health and Human Development and GM 17702 from the National Institute of General Medical Sciences, Bethesda, MD.

\section{References}

1. Duran, M., F. A. Beemer, A. S. Tibosch, L. Bruinvis, D. Ketting, and S. K. Wadman. 1982. Inherited 3-methylglutaconic aciduria in two brothers-another defect of leucine metabolism. J. Pediatr. 101:551-554.

2. Greter, J., B. Hagberg, G. Steen, and U. Söderhjelm. 1978. 3Methylglutaconic aciduria: report on a sibship with infantile progressive encephalopathy. Eur. J. Pediatr. 129:231-238.

3. Hagberg, B., O. Hjalmarson, S. Lindstedt, L. Ransnäs, and G. Steen. 1983. 3-Methylglutaconic aciduria in two infants. Clin. Chim. Acta. 134:59-67.

4. Lehnert, W., J. Scharf, and U. Wendel. 1985. 3-Methylglutaconic and 3-methylglutaric aciduria in a patient with suspected 3-methylglutaconyl-CoA hydratase deficiency. Eur. J. Pediatr. 143:301-303.

5. Robinson, B. H., W. G. Sherwood, M. Lampty, and J. A. Lowden. 1976. $\beta$-Methyl glutaconic aciduria: a new disorder of leucine metabolism. Pediatr. Res. 10:371.

6. Gibson, K. M., L. Sweetman, W. L. Nyhan, K. Narisawa, K. Roth, W. Lehnert, B. Robinson, M. Duran, and S. K. Wadman. 1985. 3-Methylglutaconyl-CoA hydratase deficiency: two different clinical and enzymatic phenotypes in 3-methylglutaconic aciduria. Pediatr. Res. 19: $248 a$.

7. Hilz, H., J. Knappe, E. Ringelmann, and F. Lynen. 1958. Methylglutaconase, eine neue Hydratase, die am Stoffwechsel verzweigter Carbonsäuren beteiligt ist. Biochem. Z. 329:476-489. 
8. DeBuysere, M. S., and M. S. Olson. 1983. The analysis of acylcoenzyme A derivatives by reverse-phase high-performance liquid chromatography. Anal. Biochem. 133:373-379.

9. Lau, E. P., B. C. Cochran, and R. R. Fall. 1980. Isolation of 3methylcrotonyl-Coenzyme A carboxylase from bovine kidney. Arch. Biochem. Biophys. 205:352-359.

10. Weyler, W., L. Sweetman, D. C. Maggio, and W. L. Nyhan. 1977. Deficiency of propionyl-CoA carboxylase and methylcrotonyl-CoA carboxylase in a patient with methylcrotonylglycinuria. Clin. Chim. Acta. 76:321-328

11. Lynen, F., J. Knappe, E. Lorch, G. Jütting, E. Ringelmann, and J. P. Lachance. 1961. Zur biochemischen Funktion des Biotins. II. Rei- nigung and Wirkungsweise der $\beta$-Methyl-crotonyl-Carboxylase. Biochem. Z. 335:123-167.

12. Messner, B., H. Eggerer, J. W. Cornforth, and R. Mallaby. 1975. Substrate stereochemistry of the hydroxymethylglutaryl-CoA lyase and methylglutaconyl-CoA hydratase reactions. Eur. J. Biochem. 53:255264.

13. Bartlett, K., and D. Gompertz. 1974. The specificity of glycine$\mathrm{N}$-acylase and acylglycine excretion in the organicacidaemias. Biochem. Med. 10:15-23.

14. Böyum, A. 1968. Separation of leucocytes from blood and bone marrow. Scand. J. Clin. Lab. Invest. 21(Suppl. 97):77-89. 